\title{
Working
}

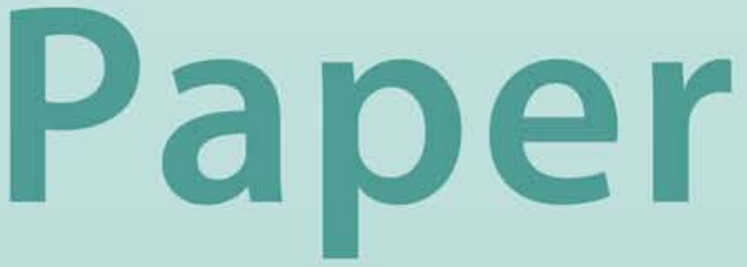




\title{
Macroeconomic Volatility: \\ The Policy Lessons from Latin America
}

\author{
Anoop Singh
}




\title{
IMF Working Paper
}

Western Hemisphere Department

\section{Macroeconomic Volatility: The Policy Lessons from Latin America ${ }^{1}$}

\section{Prepared by Anoop Singh}

July 2006

\begin{abstract}
This Working Paper should not be reported as representing the views of the IMF. The views expressed in this Working Paper are those of the author(s) and do not necessarily represent those of the IMF or IMF policy. Working Papers describe research in progress by the author(s) and are published to elicit comments and to further debate.

The recent recovery in Latin America has been impressive but also raises the question whether this represents a fundamental break with the region's history of boom-bust cycles. The paper traces how this history of macroeconomic volatility and financial crisis over the past century has adversely impacted on growth and other development indicators, and the role played by policy instability. The paper then concludes that recent policies in the region offer encouragement that these vulnerabilities are being addressed, but notes that an important agenda still remains to be addressed.
\end{abstract}

JEL Classification Numbers: E32, E52, E60, E61, and E62

Keywords: Macroeconomic volatility, Latin America, growth cycles, monetary policy, fiscal policy, banking and currency crises, structural reform, debt, inflation targeting, fiscal frameworks

Author(s) E-Mail Address: asingh@imf.org

\footnotetext{
${ }^{1}$ This paper has benefited from significant contributions from a number of IMF colleagues, including R. Benelli, N. Chalk, B. Clements, C. Faircloth, C. Towe, and J. Zettelmeyer. The standard disclaimer applies.
} 


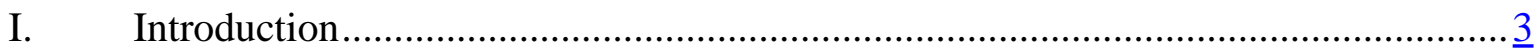

II. Macroeconomic Volatility in Latin America: A Historical Perspective...................... $\underline{3}$

III. Role of Macroeconomic Policies ......................................................................

IV. What's New This Time Around? .....................................................................

V. Remaining Agenda....................................................................................11

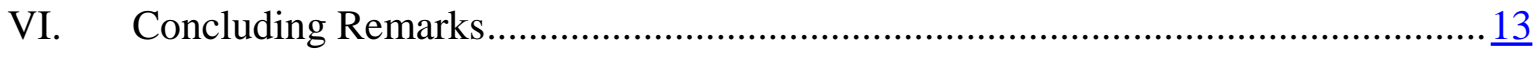

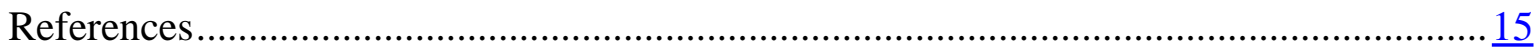

Figures

1. Inflation in Four Latin American Countries, 1880-2004 ………………………....18

2. Inflation Across Regions, 1970-2004 ..........................................................

3. Banking and Currency Crisis, 1880-1997 ……………………………………... 20

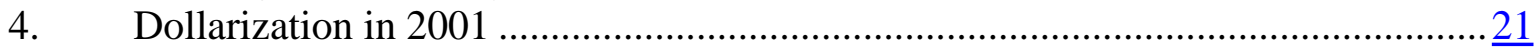

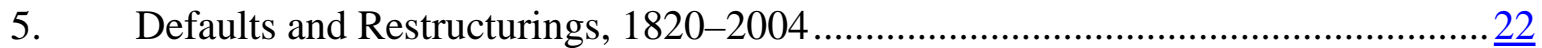

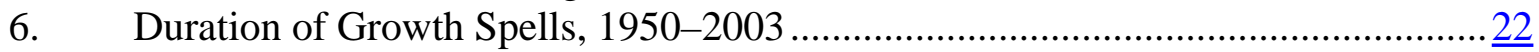

7. Episodes of Severe Contractions, by Decade, 1900-2001 ……………………......23

8. Growth and Volatility of Per Capita Real GDP, 1900-2000 ...................................24

9. Per Capita Real GDP, 1900-2001 …………………......................................

10. Composition of Growth Cycles …………………........................................25

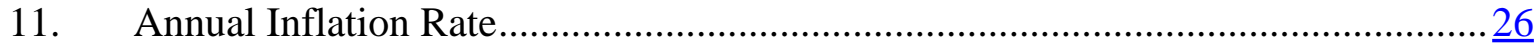

12. Fiscal Policy During Cyclical Upswings .............................................................26

13. Contributions to Change in Public Debt, 2002-2005 ……………………….....27

14. Share of Foreign Currency Bonds..............................................................27

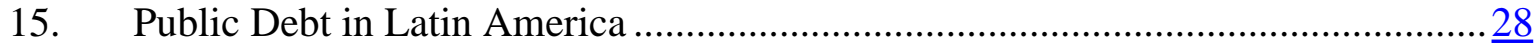

16. Net Interest Margins of Banking Sector ……………………………………... 28

17. Number of Procedures in Starting a Business..........................................................29

18. Contract Enforcement: Procedural Complexity Index.............................................. 29 


\section{INTRODUCTION}

For Latin America, after another turbulent decade, the last two years have been good. Although there remains a high degree of differentiation among countries, the region as a whole expanded at an average rate of 5 percent during 2004-2005, the fastest two-year rate of growth in two and a half decades, and has done so while generally maintaining low inflation, and current account and primary fiscal surpluses.

This paper considers whether the recent performance marks a distinct break from past cycles of booms and busts. Section II reviews the historical record of volatility in the region, while Section III traces the macroeconomic policies that have contributed to this record. Section IV assesses the current conjuncture and examines whether we should be optimistic that the region can escape the legacy of the past. Section $V$ then suggests a policy agenda that would reduce volatility and, thereby, help lift growth in the region. Brief concluding remarks are in Section VI.

\section{Macroeconomic Volatility in Latin America: A Historical Perspective}

Over the past century, countries in the Latin American region have demonstrated a marked predisposition toward macroeconomic instability. The region has been unusually prone to bouts of hyperinflation, exchange rate devaluations, failed currency reforms, banking sector collapses, and debt default:

- $\quad$ High or hyperinflation has been a recurrent phenomenon over the past century or so in all the major countries of the region (Figures 1 and 2). For example, inflation spiraled upward during the 1970s and-especially_during the 1980s and early 1990s, when it reached four-digit levels in several countries, including Argentina, Brazil, and Peru. Latin America has no parallel in any other region of the world in terms of its predisposition to periodic bouts of high inflation.

- $\quad$ Not surprisingly, this tendency toward hyperinflation has gone hand in hand with other forms of financial and exchange rate turbulence. Indeed, Latin American countries have shown an even more marked propensity toward recurrent banking and currency crises (Figure 3). This experience has left a legacy of high financial dollarization in many countries in the region (Figure 4).

- $\quad$ Relative to other regions, the frequency of implicit or explicit debt restructuring or default has also been high. Implicit default through high inflation was, often, a first resort, particularly in the 1980s and early 1990s. But the region has also experienced frequent explicit defaults (or debt-restructuring operations). Although other regions (such as Europe) have also been forced in the past to rely on debt restructuring/defaults, the persistent use of this instrument in Latin American countries has been striking (Figure 5). 
Against this background, it is not surprising that periods of strong growth have tended to be relatively short-lived, often ending in deep recessions, financial instability, and crisis. Output volatility has been high and average growth low compared with many other regions:

- $\quad$ Latin America generally compares unfavorably with other regions in its ability to sustain significant growth over prolonged periods (Figure 6). ${ }^{2}$ Recent research that aims at estimating the duration of "growth spells" suggests that Latin America trails all other major developing country regions (especially fast-growing Asia) in its ability to sustain growth. ${ }^{3}$ For Latin America, less than half of the growth spells initiated in the post-World War period continued after seven years, as opposed to over 85 percent for high-income countries and 100 percent for emerging Asia. Currently, only two countries (Chile and Trinidad and Tobago) are experiencing ongoing growth spells. The failure to maintain growth over sustained periods has been magnified by a tendency to suffer from episodes of severe contractions (Figure 7).

- $\quad$ Looking more closely at the larger economies in the region over the 1870-2004 period, one observes that their average business cycle volatility has been generally higher than in the advanced economies (Figure 8), with the exception of the period characterized by inward-looking and interventionist policies following the Great Depression. ${ }^{4}$ What sets Latin America apart from industrialized countries and other developing regions (such as East Asia) is that output volatility has not shown a clearcut downward trend; cyclical instability in Latin America rose sharply to levels that were more than double the advanced country average during the 1980s and 1990s, before declining more recently.

- $\quad$ There is also evidence of substantial cyclical co-movement across these countries. This is despite their generally limited regional trade or capital integration, most likely attributed to their common vulnerability to external shocks, especially to world commodity prices and the terms of trade.

Regarding average growth, over the past century, the region has tended to stagnate relative to both industrial and other emerging market economies. Some estimates suggest that Latin America's per capita income has actually fallen relative to that in the United States during the past century (Figure 9). ${ }^{5}$ During the past three decades, average per capita growth in the region has been only 1 percent (well below the developing country average of 23/4 percent and only around a third of the rate achieved in emerging Asia), and research illustrates that GDP per capita growth rates in Latin America may be as much as $1 / 2$ percentage point lower

\footnotetext{
${ }^{2}$ See Berg, Ostry, Leite, and Zettelmeyer (2006) for an analysis of the duration of growth spells across regions.

${ }^{3}$ Growth spells are defined as periods of statistically significant higher per capita growth, relative to previous periods, lasting at least five years and exceeding 2 percent per annum on average.

${ }^{4}$ See Aiolfi, Catão, and Timmermann (2006) and Berg and others (forthcoming) for further analysis of business cycles and patterns of growth in Latin America.

${ }^{5}$ For further discussion see Cole and others (2005).
} 
for every 1 standard deviation increase in cyclical volatility. ${ }^{6}$ This volatility has undoubtedly weighed on growth through various channels, but periodic bouts of hyperinflation, high public debt, and banking crises have certainly weighed on investment rates in the region, which have been more than 10 percentage points of GDP below those in East Asia during the past two decades. ${ }^{7}$

Finally, macroeconomic instability and low long-term growth have increased poverty and worsened social inequalities. Despite the region's recovery during the 1990s, the number of persons living in extreme poverty-defined as those living on less than \$1 per day-actually rose from 49 million in 1990 to 50 million in 2001, with much larger numbers living at "moderate" poverty levels. ${ }^{8}$ World Bank analysis also suggests that recent growth in the region has not been sufficiently "pro-poor" and that whatever growth has been achieved has not benefited incomes of those at the lower tail of the income distribution.

\section{Role of Macroeconomic Policies}

What factors can explain this history of recurrent macroeconomic instability? To be sure, external shocks have played a key role, especially given the region's dependence on external market conditions as a heavy exporter of commodities and its reliance on foreign capital, and high terms of trade volatility have been particularly detrimental and procyclical. At the same time, the role of domestic macroeconomic policies and institutions has also clearly been very significant. A recent IMF study finds that over 70 percent of the volatility of real GDP per capita growth in Latin America is due to country-specific shocks, including those from the volatility of macroeconomic policies. ${ }^{9}$ In another study, the World Bank estimates that one third of the volatility of output in the region owes to macroeconomic policies. ${ }^{10}$

The political situation in the region has undoubtedly also played a major role. Indeed, by some measures, a number of countries in Latin America have exhibited higher levels of political instability over the past decades compared with many other countries and regions. This tendency has been particularly strong for countries in Central America, but is also evident for a number of countries in South America (see, for example, Annett, 2002). And there is corresponding cross-country evidence to suggest that political instability tends to weaken macroeconomic (especially fiscal) policy discipline. Nevertheless, the region has

\footnotetext{
${ }^{6}$ See Loayza, Fajnzylber, and Calderón (2004).

${ }^{7}$ See Inter-American Development Bank (IDB) (2001). It is noteworthy that the recent rebound in growth in Latin America has been most robust in low-debt countries, even though high-debt countries experienced larger output gaps during this period.

${ }^{8}$ See Saavedra and Arias (2005), who show that there are much higher poverty rates recorded in countries such as Bolivia and Honduras but that relatively high rates persist even in countries such as Chile and Uruguay. The authors suggest this is, in part, due to the self-perpetuating dynamics of extreme income inequality but also is a result of important ethnic divisions in certain countries.

${ }^{9}$ IMF (2005a).

${ }^{10}$ De Ferranti, and others (2000).
} 
witnessed growing democratization, a major achievement, and this is beginning to have a stabilizing influence on macroeconomic policies-especially in the political commitment to low inflation.

Until recently, monetary policy has generally amplified the cycle in the region. Partly in response to pressures to provide fiscal financing, monetary policymakers have in the past been forced to provide excessively easy access to central bank credit, thereby causing high inflation, leaving growth phases highly vulnerable to macroeconomic and financial instability. These tendencies have often been compounded by the tendency of central banks in the region to act pro-cyclically-loosening during upswings or tightening in the face of negative shocks. For example, Kaminsky, Reinhart, and Végh (2004) find a procyclical relationship between policy interest rates and output in most Latin American countries over 1960-2003, and that fiscal policy has tended to reinforce the cyclicality of net capital inflows. ${ }^{11}$ Moreover, the recurrence of monetary accommodation and high inflation has left a legacy of currency and banking system instability, as well as dollarization, adding to the complexity of monetary management and amplifying volatility.

Fixed-type exchange rate regimes have tended to dominate the region for much of recent history and have magnified procyclical tendencies. The evidence suggests that fixed exchange rates tended to significantly increase (by a factor of two) the effects of terms-oftrade shocks on output in the region. ${ }^{12}$ This result reflects the region's heavy dependence on commodity exports and the relative lack of domestic price and labor market flexibility needed to allow economies to adjust to external conditions. Moreover, as was demonstrated during the past decade, fixed exchange rates have been ineffective in disciplining fiscal and monetary policies, and may also have encouraged excessive borrowing abroad.

However, it is fiscal policy - and frequent changes in the fiscal stance- that has been the primary driver of macroeconomic instability in the region. Bouts of fiscal volatility have been triggered partly by the tendency of fiscal policymakers to act in a pro-cyclical manner, overextending the public sector during boom times and sharply curtailing spending during downturns, and has amplified cyclical instability in the wider economy. Coupled with heavily dollarized economies, fixed exchange rates, and weak central banks, the result has been cycles involving a ratcheting up of public debt, monetary accommodation, accelerating inflation, and eventual crisis. ${ }^{13}$ The evidence suggests that Latin America's fiscal volatility over the 1960-2000 period was generally higher than other regions. While the sources of fiscal volatility are unique to individual countries, there have been some important common elements:

\footnotetext{
${ }^{11}$ The authors illustrate the relationship between fiscal policy and capital flows by demonstrating a negative correlation between the inflation tax and the cyclical component of net capital inflows.

12 Edwards and Levy Yeyati (2003).

${ }^{13}$ For recent work on the link between, fiscal policy and inflation, including in Latin America, see Gavin and Perotti (1997); Fischer, Sahay, and Végh (2000); Catão and Terrones (2005); and Kwon, McFarlane, and Robinson (2006).
} 
- $\quad$ The historical experience suggests that a key common element has been high volatility in government spending, especially investment. ${ }^{14}$ Besides the direct effect on overall activity, frequent changes in the fiscal stance have signaled a lack of consistency and predictability in policy and weighed heavily on private investment and productivity.

- Institutional factors have been especially important. These have been manifested in a number of ways. Budget rigidities have been one such institutional factor. The generally high level of earmarking of revenues and constitutional constraints involving spending floors has meant that countries in the region have been unable to reduce some categories of spending in the face of downturns or to redirect resources in response to changing priorities.

- $\quad$ Fiscal decentralization and intergovernmental relations have been another determining institutional factor. In many cases, the burden of macroeconomic adjustment in Latin America has fallen on the federal government alone. In other instances, the inability to effectively control the borrowing of local governments has diminished fiscal discipline and contributed to fiscal crises. ${ }^{15}$

- $\quad$ Recurrent banking crises have also left a lasting impact on the public debt as the costs of banking failures were typically borne heavily by the state. Such crises since 1990 have been a major cause of the rise in the public debt in the region during this period.

- Institutional weaknesses have also arisen from situations of high unemployment and poverty, as well as extreme income disparities. Such weaknesses typically tend to erode the political commitment to policy discipline and leave governments vulnerable to pressures to undertake popular but destabilizing discretionary fiscal policy. Latin America is typified by weak governance in public institutions, which has exacerbated the competition for budgetary resources and likely imparted greater spending volatility. ${ }^{16}$

Debt dynamics have also contributed to fiscal instabilities. Given the history of volatility and the related underdevelopment of domestic capital markets, countries in the region have tended to borrow excessively in foreign currencies, and in short maturities that were inherently inconsistent with sustaining exchange rate pegs or macroeconomic stability. Moreover, because of the legacy of earlier crises, the region has become "debt intolerant," generally confronting interest rates well above average growth rates. The simple arithmetic in such cases is, therefore, that any borrowing has been inherently unstable, a situation that has

\footnotetext{
${ }^{14}$ For recent studies on the cyclicality, of government expenditures in Latin America, see Gavin and Perotti (1997); Kaminsky, Reinhart, and Végh (2004); Akitoby, and others (2005); and Clements, Faircloth, and Verhoeven (2006). For more general reviews of the cyclicality of fiscal policy in industrial and developing countries, see IMF (2005d).

${ }^{15}$ See Ter-Minassian (1997) and Mussa (2002).

${ }^{16}$ See Alesina, and others (1999); and Stein, Talvi, and Grisanti (1999).
} 
been exacerbated in Latin America by the fact that risk premia, contagion, and borrowing costs have tended to increase sharply when the region faces adverse shocks. ${ }^{17}$ Similarly, high debt has limited the scope for policy makers to respond counter-cyclically in the face of downturns.

\section{What's NeW This Time Around?}

How much of Latin America's recent successes stem from the external environment? Most importantly, the region's terms of trade have improved by 14 percent since end-2002-more so in South America-largely due to the region's importance as a supplier of oil and non-oil commodities. In addition, low world interest rates and abundant global liquidity have been an enormous boon to investment-grade countries (such as Mexico) and countries recovering from crises (such as Brazil). At the same time countries in the region are benefiting from a growth spurt that reflects also cyclical recoveries, with an output gap that is now closing in many countries.

Encouragingly, though, steady progress in advancing market-based reforms and entrenching sound macroeconomic policy frameworks also seems to be bearing fruit. We are seeing concerted efforts toward fiscal consolidation and a willingness to tackle inflationary pressures at an early stage. This has resulted in a more balanced pattern of growth than in earlier recoveries and avoided the over-appreciation of currencies and widening external current account balances that have arrested earlier recoveries (Figure 10). Indeed, the current cycle has been supported by generally strong and geographically diversified export growth and terms of trade gains, anchored by more flexible and competitive currencies. The resulting current account surpluses have raised reserves markedly and have reduced the dependence on external capital inflows. These developments give hope that the current expansion will be more enduring than that of previous cycles.

This more optimistic outlook reflects a stronger political commitment to low inflation. This commitment has been reflected in a range of institutional and operational reforms to improve central bank autonomy, adopt inflation targeting, and allow for much greater exchange rate flexibility, in succession to the exchange-rate stabilization plans that were initially followed in the 1990s. In particular, Brazil, Chile, Colombia, Mexico, and Peru, adopted inflationtargeting frameworks in the late 1990s and early 2000s, and many other countries are aiming in this direction. This generalized shift in monetary frameworks appears, thus far, to have been highly effective (Figure 11). Inflation has averaged just 71/2 percent in the region since 2000, despite the jump in world oil prices, and a far cry from the rate in excess of 500 percent that prevailed in 1990. The new regimes have been extraordinary successful in anchoring inflation expectations and, once policy credibility within the context of these regimes was established, in allowing monetary policy to play a more active countercyclical

\footnotetext{
${ }^{17}$ See Borenszstein, and others (2004).
} 
role. This, in turn, suggests that countries in the region will be much more resilient to shocks going forward. ${ }^{18}$

The region's vulnerability to crisis has also been mitigated by efforts to strengthen banking systems. The lessons learned during the crises of the past decade have led countries in Latin America to bolster bank supervision and financial sector regulation, especially with regard to loan-classification and provisioning standards; implement prompt corrective-action frameworks; and to provide greater independence and power to financial sector regulators. ${ }^{19}$ Although there remains more work to be done, the decline in nonperforming loan ratios and strengthened capital adequacy ratios suggests financial systems have become much more resilient. $^{20}$

But, given the centrality of fiscal weakness to past volatility, it is especially encouraging to see the improvements in this area (Figure 12). Most countries in the region have placed greater emphasis on ensuring consistency between fiscal and monetary policies and frameworks. These efforts have led a number of countries in the region to undertake important institutional reforms to help discipline fiscal policy, including:

- $\quad$ Chile's fiscal rule that successfully targets structural surpluses equivalent to 1 percent of GDP in the accounts of the central government;

- Brazil's various fiscal norms and regulations, including the fiscal responsibility law and the debt restructuring agreements with sub-national governments, and rules limiting public wage expenditures; and

- $\quad$ Fiscal Responsibility and Transparency Laws in both Colombia and Peru.

A welcome signal of the success of these changes has been the significant decline in debt-toGDP ratios in Latin America since 2002. ${ }^{21}$ By end-2005, the average gross public debt-toGDP ratio had fallen by about 26 percentage points compared with end-2002, with declines in all the nine LAC countries sampled. The drop in the LAC average was much more pronounced than in other regions (Figure 13).

\footnotetext{
${ }^{18}$ For a discussion, see IMF (2005c).

${ }^{19}$ For further discussion, see Singh and others (2005).

${ }^{20}$ See IMF (2005b).

${ }^{21}$ The country sample described in this section (except in Figures 12 and 14) consists of Argentina, Brazil, Chile, Costa Rica, Ecuador, Mexico, Peru, Uruguay, and Venezuela. These countries account for 90 percent of the region's GDP at market exchange rates (85 percent of the region's purchasing power parity (PPP)-adjusted GDP). All averages cited in this section are based on weights constructed from average PPP-adjusted gross domestic products (over 1990-2005), while market exchange rates are used for all the other calculations.
} 
To be sure, much of the turnaround in the debt has reflected relatively benign global and domestic circumstances. ${ }^{22}$ In particular, estimates suggest that strong economic growth has contributed to an average reduction of about $9 \frac{1}{3}$ percent of GDP in the average debt ratio, especially in Argentina and Uruguay, as these countries rebounded from severe downturns experienced during their financial crises. Real interest rates have also fallen sharply, partly in response to low global interest rates and the marked narrowing in risk spreads. ${ }^{23}$ Moreover, the rebound in nominal exchange rates - by an average of around 15 percent between 2002 and 2005-is also estimated to have contributed to reduce the average debt ratio by 5 percent of GDP, reflecting the effect of the still large share of foreign currency-denominated debt.

But it is also clear that many countries in Latin America have achieved remarkable turnarounds in their fiscal positions. On average, primary fiscal surpluses of $3 \frac{1}{3}$ percent of GDP were maintained during 2003-2005, over twice the average surplus achieved during the past decade and much better than in other emerging markets, where primary deficits have been the norm in recent years. Although this improvement has partly reflected the boost to revenues that oil and other commodity exporters in the region have experienced, the bulk of this improvement has been in high-debt countries and has contributed to about 10 percentage points of the reduction in the region's average debt ratio. ${ }^{24}$

The composition of fiscal consolidation and its structural content has generally also been encouraging:

- $\quad$ Adjustment in high debt countries has relied on spending cuts-with the average expenditure-to-GDP ratio falling after 2002 - that more than offset a declining revenue-to-GDP ratio (which peaked in 2002). By contrast, low debt countries have relied mostly on revenues increases, partly reflecting the revenue effects of sharp improvements in the terms of trade (e.g., in Chile and Venezuela), or continued pressures on spending.

- $\quad$ The adjustment has reflected improvements in structural positions and not just a cyclical rebound. In recent years, spending growth has generally been contained, despite the recovery in overall activity, in sharp contrast with the experience in the recoveries at the beginning of the 1990s and after the tequila crisis. It is also encouraging that the countries where discretionary policy represents the largest share of the cumulative improvement in primary balances in 2003-2005 are those countries

\footnotetext{
${ }^{22}$ Argentina's debt restructuring helped reduce that country's debt ratio by 27 percent of GDP, accounting for 4 percentage points of the decline in Latin America's average debt ratio (26 percentage points). Nevertheless, the country's debt ratio remained at about 90 percent of GDP at the end of 2005 (including arrears to creditors).

23 The average carrying cost of debt fell from 15 percent in 2002 to about 81/2 percent in 2004 (although it rose slightly in 2005, driven by increases in short-term interest rates in Brazil).

${ }^{24}$ During a given year, high -(low-) debt countries are those countries with debt ratios equal or above (below) the region's median debt ratio during the same year. Because the median debt ratio changes over time, the groups of high- and low- debt countries change over time. For example, Argentina belonged to the low-debt group from 1992 until 1998 (excluding 1997), but then switched to the high-debt group. In 2004-2005, the high-debt group includes Argentina, Brazil, Costa Rica, Mexico, and Uruguay.
} 
that have recently emerged from financial crises. These improvements bear close watching against more recent evidence that points to an upturn in primary fiscal spending over the past year.

The recent decline in debt has been accompanied by an improvement in debt management. The most notable improvement has been in a reduction in foreign-currency denominated debt, as several countries - notably, Brazil, Chile, Colombia, Mexico, and Peru-have increased their reliance on debt issuance in domestic currencies (Figure 14), including in international markets (Brazil, Colombia, and Uruguay) ${ }^{25}$ The decline in the share of foreign currency debt has also benefited from an appreciation of the real exchange rate, and from the debt exchange in Argentina, which increased the share of debt in the local currency. Many governments in the region have also taken advantage of the current benign international financial conditions to prefinance debt ahead of a full election calendar and potentially less favorable global market conditions.

The case of Brazil illustrates the importance of strengthening debt management efforts in the region. In Brazil, there has been extraordinary progress in reducing the share of debt linked to or denominated in foreign currency (from 56 percent at the end of 2002 to 11 percent at end-June 2006). This was a key source of vulnerability that helped fuel the 2002 crisis. However, debt managers have been required to make careful trade-offs that are bounded by the market's appetite for particular instruments. While the share of foreign denominated debt has fallen, the share of debt linked to short-term interest rates (the SELIC) has risen from 32 in December 2002 to a peak of 48 percent of the total stock in July 2005, before receding to 44 percent at end-June. The trade-off is also evident in the reduction of the average debt maturity from 33 months at the end of 2002 to a trough of 27 months in November 2005. Ongoing efforts to lengthen maturities have already raised the average figure to 29 months in June 2006.

\section{REMAining Agenda}

Thus, the region has made important strides in addressing the roots of macroeconomic stability and still faces a relatively favorable environment for making further progress. However, looking ahead, and against the background of the region's history, it is not surprising that I would give primary importance to the need for continued policy and institutional steps to reduce public debt and strengthen fiscal frameworks among the core medium-term challenges for the region. Other related priorities include: (i) solidifying the commitment to low inflation; (ii) improving financial intermediation; and (iii) structural reforms to improve macroeconomic flexibility. These reforms priorities are discussed briefly below:

Lowering public debt. Notwithstanding the gains made in recent years, the core challenge remains to ensure that policies and institutional frameworks support sustained and rapid further debt reduction. Public debt in Latin America remains at just over 50 percent of GDP,

\footnotetext{
${ }^{25}$ At the end of 2004, Latin America's weighted average share of foreign currency debt stood at about 39 percent, down from 56 percent at the end of 2000.
} 
still higher than at the end of 2001, and debt ratios in many countries are well above this mark (Figure 15). There is considerable empirical evidence to suggest that debt at this level still retards growth, crowds out productive social spending, and breeds crises, and countries need to aim to bring debt ratios down below the 40 percent of GDP benchmark that is often thought to be "safe" —and a lower benchmark can apply depending on individual circumstances. Ongoing efforts to lower debt ratios will need to be supported by concerted efforts to develop domestic capital markets in order to enable a further reduction of the dependence on short-term and foreign-currency linked instruments.

Strengthening fiscal frameworks. Again, substantial gains have been made on this front among many countries in the region, which are paying off in terms of primary surpluses. But in many countries, too much spending continues to be directed to inefficient programs and too little is being directed toward the public infrastructure that will support growth and stability, or toward well-targeted social programs that can ensure that the benefits of growth are well distributed. Although fiscal spending has picked up over the past year-and warrants close monitoring - early indicators do not suggest any significant improvement in this composition. Moreover, governments continue to be overly bound by earmarks that distort spending and promote inappropriate fiscal responses to cyclical and other shocks. In addition, weaknesses in intergovernmental relations and in tax administration also need to be addressed, and those countries (such as Ecuador, Mexico, and Venezuela) that are currently enjoying fiscal windfalls from high oil prices should ensure that a larger proportion of these windfalls are saved. Although fiscal rules and fiscal responsibility legislation, by themselves, are no panacea, the experience in many countries still suggests that these mechanisms can play an important role in developing and anchoring a social consensus for fiscal discipline. ${ }^{26}$

Solidifying the commitment to low inflation. The progress that has been made in reducing and stabilizing inflation in Latin America during the past decade is remarkable and provides a testament to the success of flexible exchange rate/inflation-targeting frameworks. However, the use of inflation targets is not yet widespread and even those countries that have adopted targets will face tests in coming years, including the expected rise in global interest rates, the anticipated unwinding of global current account imbalances, and the closing of output gaps. Faced with these uncertainties, it is even more essential than ever that central banks strengthen policy transparency, an area where many Latin American countries rank behind Europe, Asia, and the Middle East and Central Asia. ${ }^{27}$ Moreover, the high degree of turnover among central bank governors in Latin America provides an important illustration of the need to strengthen the de facto operational autonomy of the region's central banks. ${ }^{28}$

\footnotetext{
${ }^{26}$ The experience with fiscal rules and responsibility laws, including in Latin America, is examined in IMF (2005d).

27 Carstens and Jácome (2005).

${ }^{28}$ Following reforms, central bank governors in Latin America have, on average, stayed in office for about two and a half years-well below the typical term of appointment (between 4 and 6 years). This turnover is also greater than in industrial countries, where central bank governors routinely complete their terms and sometimes have them extended (Carstens and Jácome, 2005).
} 
Deepening financial sector reform. Financial intermediation, especially access to credit, often lags behind other regions and real interest rates and deposit-lending spreads remain too high in many countries (Figure 16). Going forward, financial sectors in the region need to be transformed from sources of vulnerability to institutions of economic strength capable of delivering the sustained financial resources essential to underpin economic growth. Further efforts to strengthen banking regulation and supervision, reduce dollarization in the banking system, improve accounting and auditing standards, and revise bankruptcy laws to enhance the ability of lenders to recover value from distressed loans will be needed. The deepening of local bond and equity markets, as part of the essential agenda discussed above, will improve diversify the sources of finances for enterprises.

Structural reforms to improve macroeconomic flexibility. The lack of strong marketbased institutions in Latin America has meant that labor and product markets have lacked the flexibility to cope with shocks. This has undoubtedly contributed to policy instability, since policymakers have been forced to step in and mitigate the effects of shocks. Detailing the range of reforms that are needed in this area is beyond the scope of this paper and these have been discussed extensively elsewhere, but should include measures to improve the effectiveness and resilience of financial sectors; labor market reforms that enhance mobility across sectors; opening up economies to international trade; and improving institutions relevant for the business climate (Figures 17 and 18), such as legal and regulatory systems. ${ }^{29}$

\section{CONCLUding REMARKS}

The discussion above has demonstrated that, thus far, Latin America has been relatively less successful than other regions in exploiting the powerful influences of globalization and democracy that have swept the global landscape, especially in the last two decades. To an important extent, the region's long history of macroeconomic volatility has been a major constraint, linked to weaknesses in institutions and consequent instability in policies. After the crises of the past decade, however, there are encouraging signs that steps are being taken to strengthen policy frameworks and lock in more stable macroeconomic environments.

Nevertheless, the region still faces the challenge of marshaling the social and political coalitions needed to take this process forward. The region's heavy near-term political calendar should open the door to such opportunities. Indeed, the entrenchment of democracy in the region, as witnessed by the successful and peaceful conclusion of democratic elections generally across the region over the past two decades, augurs well for consolidating popular support for the market-based institutions that are needed to support macroeconomic stability.

Looking forward, the IMF intends to do its part and collaborate closely with countries in the region to assist in this effort. In recent years, its surveillance and policy analysis has begun to place a much greater emphasis on potential vulnerabilities, financial sector issues, debt sustainability, and institutional strengthening, while there has been a sea change in economic

${ }^{29}$ See Singh and others (2005). 
transparency on the part of countries as well as within the IMF. The IMF has also been emphasizing the important role that multilateral trade liberalization can play in opening new markets for countries in the region, spurring improvements in domestic institutions, and promoting stability. More directly and on the operational front, the IMF has just recently provided considerable debt relief to four countries in the region under the Group of Eight's Multilateral Debt Relief Initiative (MDRI) initiative, and has introduced new instrumentsthe Policy Support Initiative and an Exogenous Shocks Facility-that should further assist countries in Latin America in promoting macroeconomic stability and growth. 


\section{REFERENCES}

Aiolfi, Marco, Luis Catão, and Allan Timmermann, 2006, "Common Factors in Latin America's Business Cycles," IMF Working Paper 06/49 (Washington: International Monetary Fund).

Akitoby, Bernard, Benedict Clements, Sanjeev Gupta, and Gabriela Inchauste, 2005, "Public Spending, Voracity, and Wagner's Law in Developing Countries,” European Journal of Political Economy, forthcoming.

Alesina, Alberto, Richard Hausmann, Rudolf Hommes, and Ernesto Stein, 1999, "Budget Institutions and Fiscal Performance in Latin America,” Journal of Development Economics, Vol. 59, No. 2, pp. 263-73.

Annett, Anthony, 2002, “Social Fractionalization, Political Instability, and the Size of Government,” Staff Papers, International Monetary Fund, Vol. 48, No. 3, pp. 561-92.

Berg, Andy, Jonathan Ostry, Carlos Leite, and Jeronimo Zettelmeyer, 2006, "What Makes Growth Sustained?" (unpublished, Washington: International Monetary Fund).

Bordo, Michael, Barry Eichengreen, Daniela Klingebiel, and Maria Soledad Martinez-Peria, 2001, "Is the Crisis Problem Growing More Severe?" Economic Policy, Vol. 32 (April), pp. 51-82.

Borensztein, Eduardo, Marcos Chamon, Oliver Jeanne, Paolo Mauro, and Jeromin Zettelmeyer, 2004, Sovereign Debt Structure for Crisis Prevention, IMF Occasional Paper No. 237 (Washington: International Monetary Fund).

Carstens, Agustín, and Luis Jácome, 2005, “Taming the Monster: How Latin America’s Central Banks Survived Hyperinflations to Become Guardians of Price Stability,” Finance \& Development, Vol. 42 (December), pp. 26-29.

Catão, Luis, and Marco Terrones, 2005, “Fiscal Deficits and Inflation,” Journal of Monetary Economics, Vol. 52, pp. 529-54.

Clements, Benedict, Christopher Faircloth, and Marijn Verhoeven, 2006, "Public Spending in Latin America: Trends and Policy Challenges” (unpublished, Washington: International Monetary Fund).

Cole, Harold, Lee E. Ohanian, Alvaro Riascos and James A. Schmitz Jr., 2005, "Latin America in the Rearview Mirror,” Journal of Monetary Economics, Vol. 52, pp. 69107.

De Ferranti, David, Guillermo Perry, I. Gill, and Luis Servén, 2000, Securing Our Future in a Global Economy (Washington: World Bank). 
Edwards, Sebastian, and Eduardo Levy Yeyati, 2003, "Flexible Exchange Rates as Shock Absorbers,” NBER Working Paper No. 9867 (Cambridge, Massachusetts: National Bureau of Economic Research).

Fischer, Stanley, Ratna Sahay, and Carlos Végh, 2000, “Modern Hyper- and High Inflations,” NBER Working Paper No. 8930 (Cambridge, Massachusetts: National Bureau of Economic Research).

Gavin, Michael, and Roberto Perotti, 1997, “Fiscal Policy in Latin America,” NBER Macroeconomics Annual 1997 (Cambridge, Massachusetts: MIT Press).

Sahay, Ratna, and Rishi Goyal, 2006, "Volatility and Growth in Latin America: An Episodic Approach" (unpublished, Washington: International Monetary Fund).

International Monetary Fund (IMF), 2005a, “Two Current Issues Facing Developing Countries” in World Economic Outook, April, Chapter II (Washington). , 2005b, Global Financial Stability Report, September (Washington). , 2005c, “Does Inflation Targeting Work in Emerging Markets?” World Economic Outlook, September, Chapter IV (Washington).

, 2005d, "Promoting Fiscal Discipline Over the Business Cycle," forthcoming as an IMF Occasional Paper prepared by the Fiscal Affairs Department, (Washington).

Inter-American Development Bank (IADB), 2001, Competitiveness: The Business of Growth, Economic and Social Progress in Latin America: (Baltimore: Johns Hopkins University Press).

Kaminsky, Graciela, Carmen Reinhart, and Carlos Végh, 2004, "When It Rains, It Pours: Procyclical Capital Flows and Macroeconomic Policies,” NBER Working Paper No. 1078 (Cambridge, Massachusetts: National Bureau of Economic Research).

Kwon, Goohoon, Lavern McFarlane, and Wayne Robinson, 2006, "Public Debt, Money Supply, and Inflation: A Cross-Country Study and Its Application to Jamaica” IMF Working Paper No. 06/121 (Washington: International Monetary Fund).

Loayza, N., P. Fajnzylber, and C. Calderón, 2004, “Economic Growth in Latin America and the Caribbean: Stylized Facts, Explanations, and Forecasts,” Central Bank of Chile Working Paper No. 265 (Santiago).

Maddison, Angus, 2001, The World Economy: a Millennial Perspective (Paris: Organization for Economic Cooperation and Development).

Mussa, Michael, 2002, “Argentina and the Fund: From Triumph to Tragedy, ” Policy Analyses in International Economics No. 67 (Washington: Institute for International Economics). 
Saavedra, Jaime, and Omar S. Arias, 2005, "Stuck in a Rut: Avenues for Combating Persistent Poverty and Inequality in Latin America,” Finance \& Development, Vol. 42 (December) pp. 18-22.

Singh, Anoop, Agnès Belaisch, Charles Collyns, Paul De Masi, Reva Krieger, Guy Meredith, and Robert Rennhack, 2005, Stabilization and Reform: A Macroeconomic Perspective on the Experience Since the Early 1990s, IMF Occasional Paper No. 238 (Washington: International Monetary Fund).

Stein, Ernesto, Ernesto Talvi, and A. Grisanti, 1999, “Institutional Arrangements and Fiscal Performance,” in Fiscal Institutions and Fiscal Performance, ed. by J. Poterba and J. Von Hagen, (University of Chicago Press).

Sturzenegger, Federico, and Jeromin Zettelmeyer, 2006, Debt Defaults and Lessons from a Decade of Crises, forthcoming (Cambridge, Massachusetts: MIT Press).

Ter-Minassian, Teresa, ed., 1997, Fiscal Federalism in Theory and Practice (Washington: International Monetary Fund). 
Figure 1. Inflation in Four Latin American Countries, 1880-2004
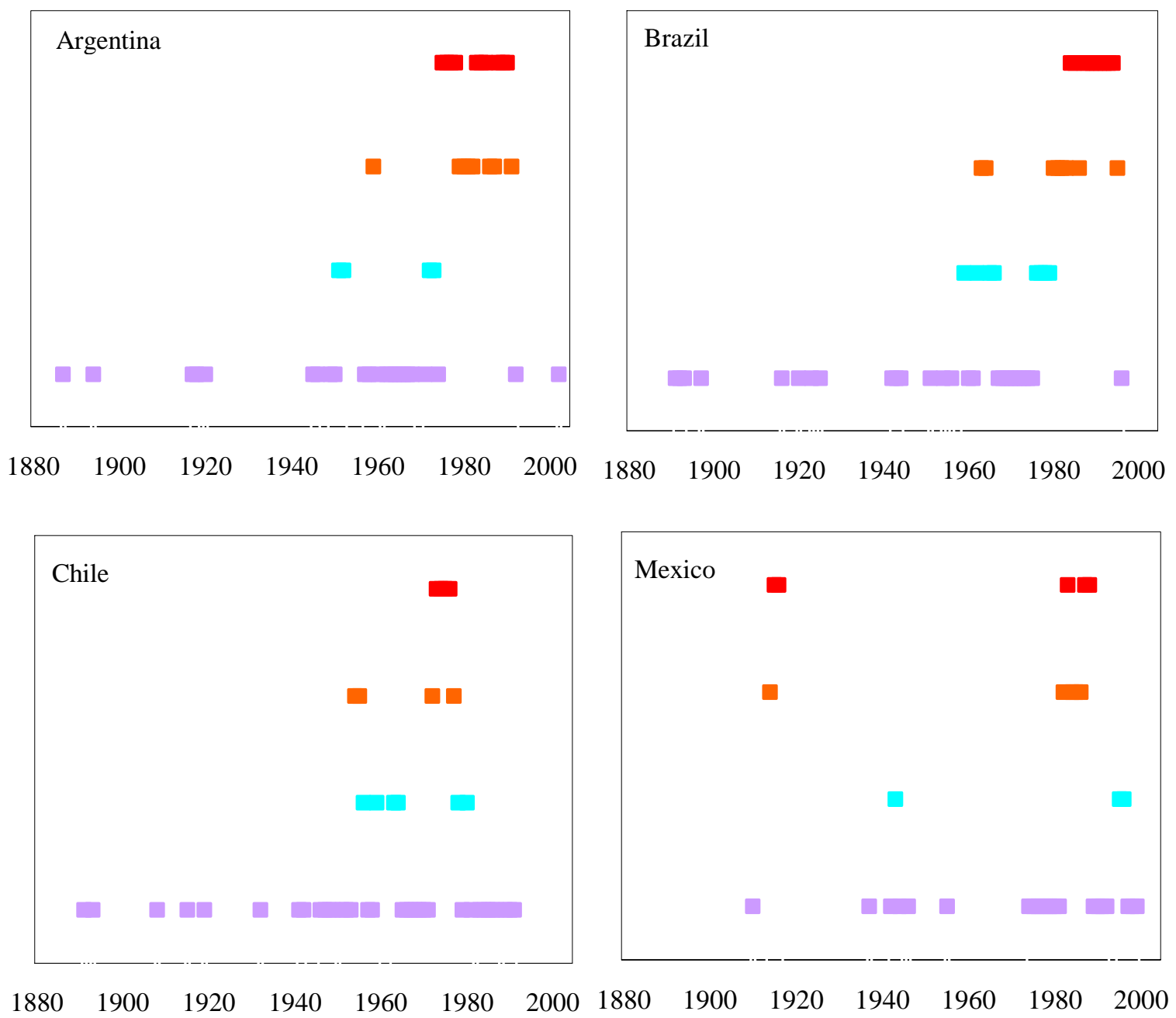

Source: Aiolfi, Catão, and Timmermann (2006).

$$
\begin{aligned}
& =\text { Between } 15 \text { and } 30 \text { percent } \\
& =\text { Between } 50 \text { and } 100 \text { percent }
\end{aligned}
$$$$
\text { = Between } 30 \text { and } 50 \text { percent }
$$$$
\text { = Above } 100 \text { percent }
$$ 
Figure 2. Inflation Across Regions, 1970-2004
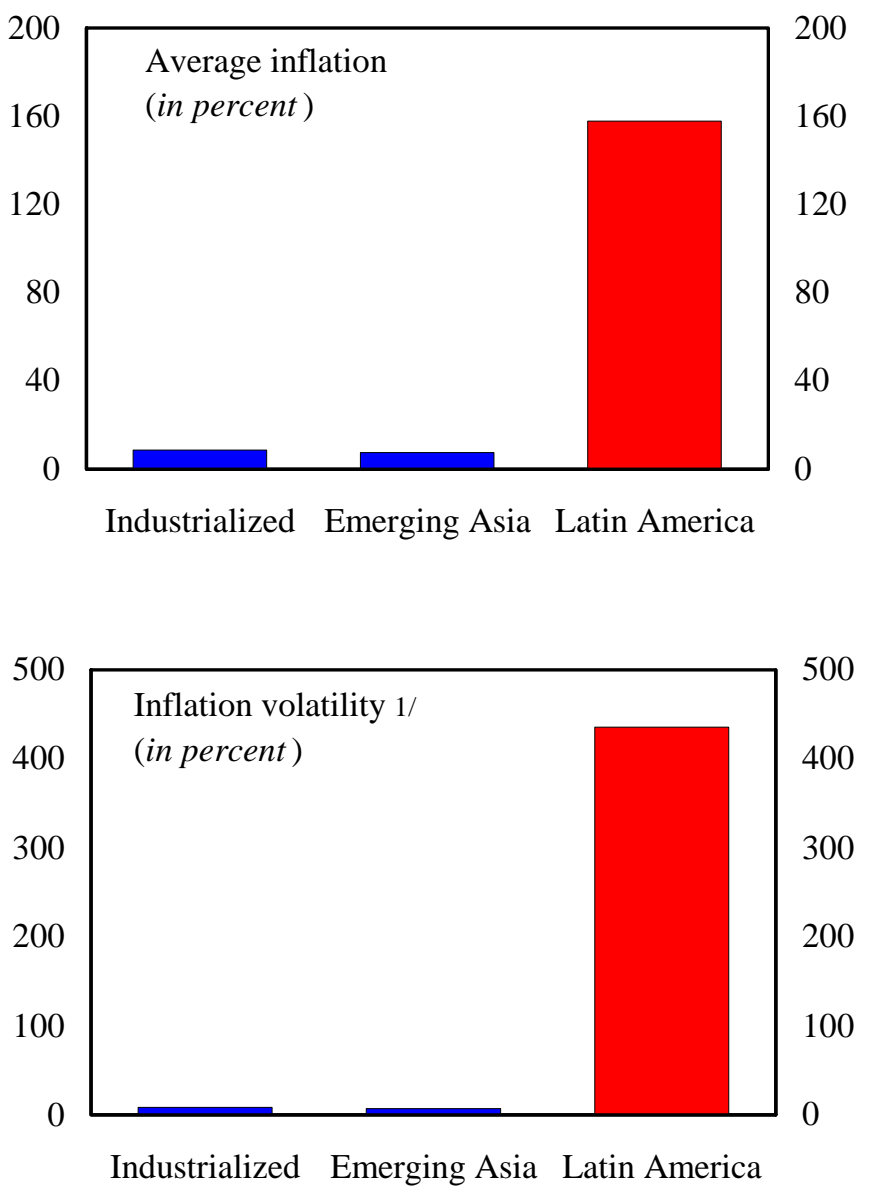

Source: Sahay and Goyal (2006).

1 / Defined as the average standard deviation of the inflation rate over the sample period. 
Figure 3. Banking and Currency Crises, 1880-1997

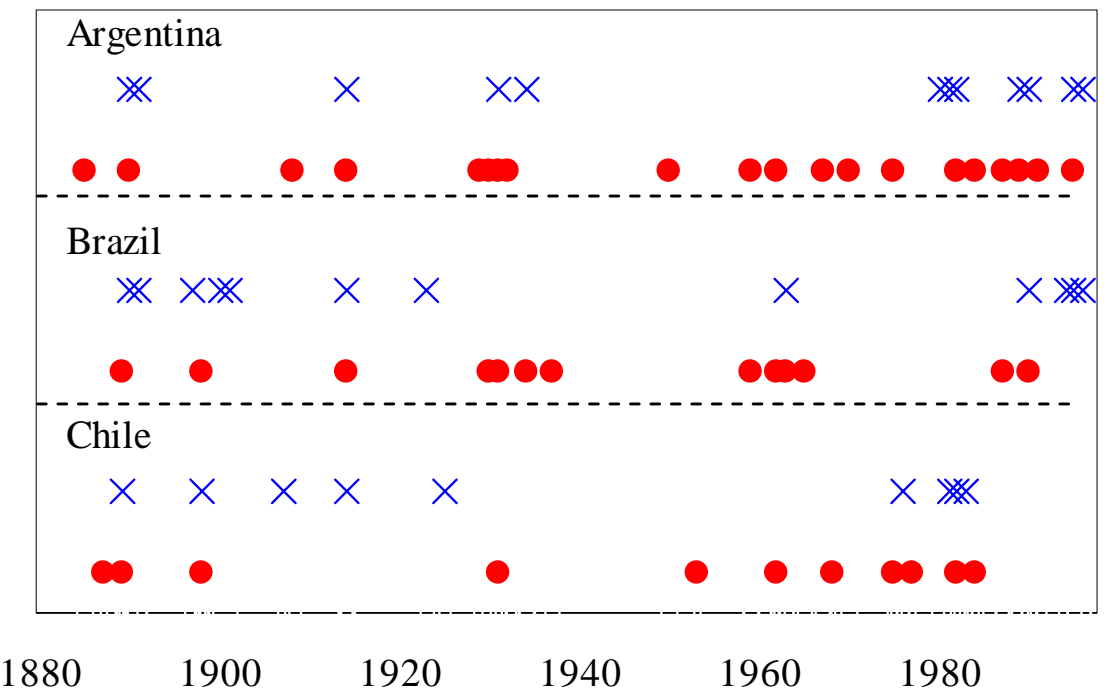

Source: Bordo, Eichengreen, Klingebiel, and Martinez-Peria (2000)

$$
X=\text { Banking crisis } \quad=\text { Currency crisis }
$$


Figure 4. Dollarization in 2001

(in percent of total deposits)

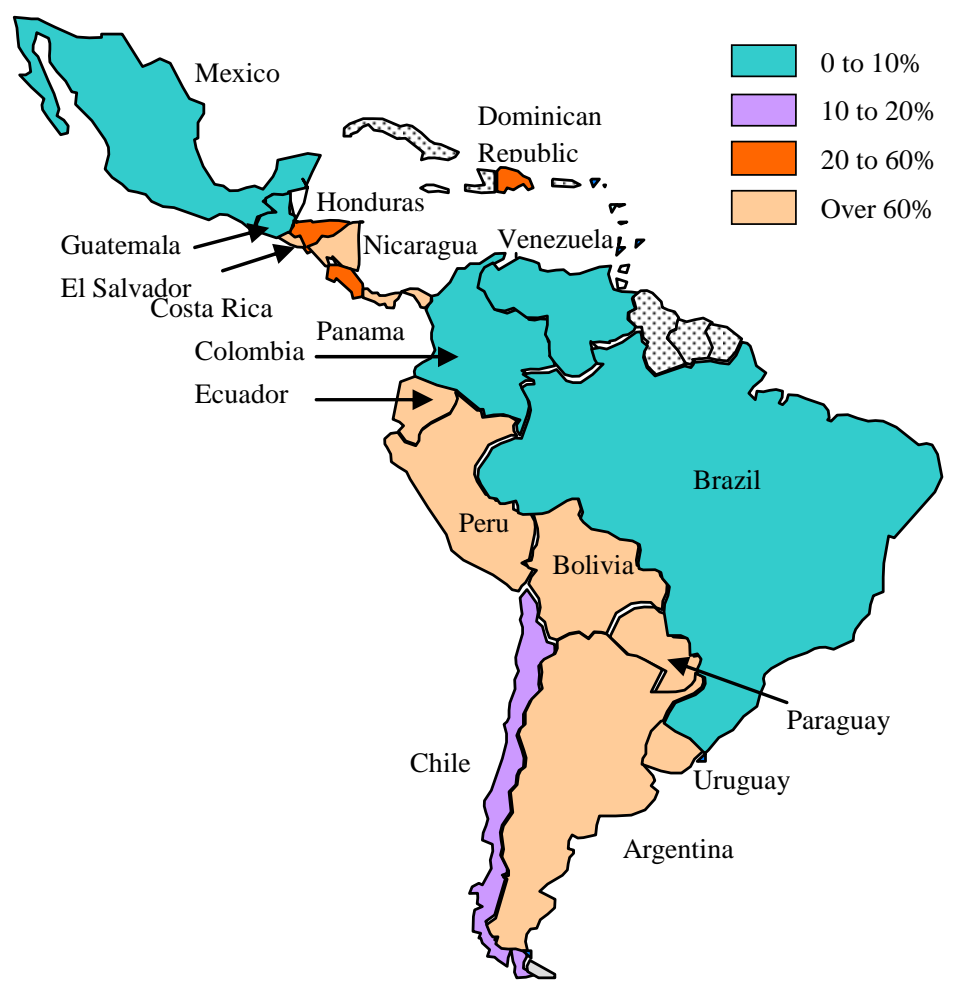

Sources: Country authorities; and staff estimates.

Note: The denominations used and the boundaries shown on this map do not imply any judgment by the IMF on the legal status of any territory or any endorsement or acceptance of such boundaries. 
Figure 5. Defaults and Restructurings, 1820-2004

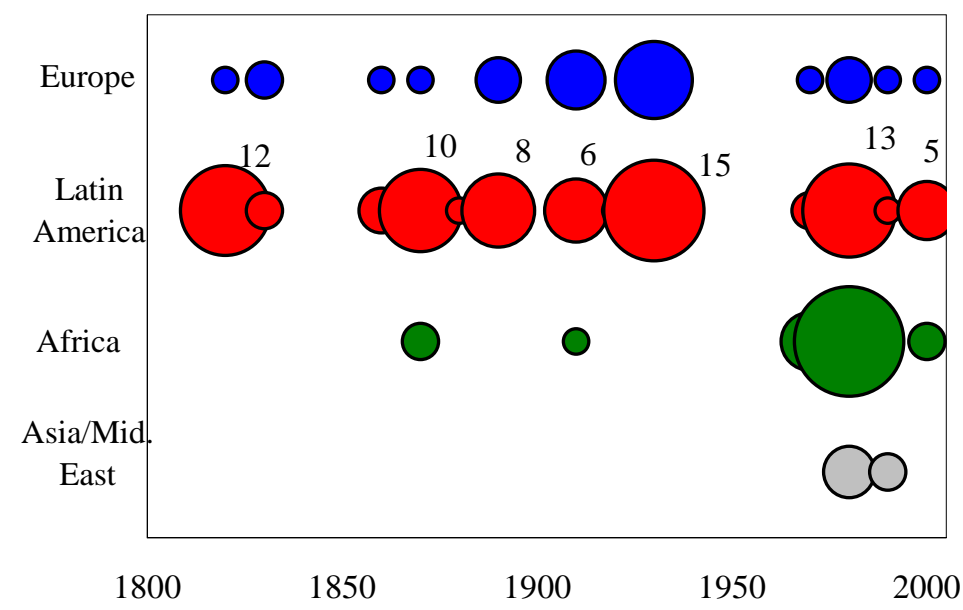

Source: Sturzenegger and Zettelmeyer (2006). Number of episodes of default or restucturing per
decade. A larger circle indicates more episodes.

Figure 6. Duration of Growth Spells, 1950-2003

(percent of countries achieving the indicated duration)

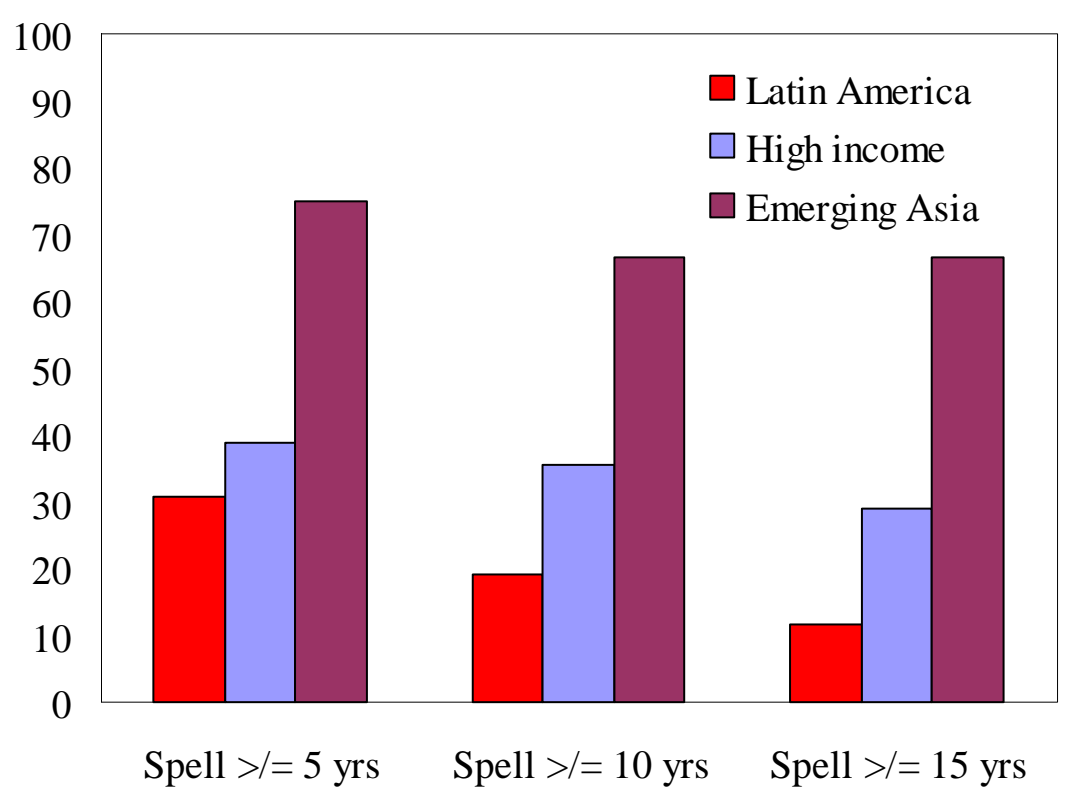

Source: Berg, Ostry, Leite, and Zettelmeyer (2006). 
Figure 7. Episodes of Severe Contractions, by Decade, 1900-2001

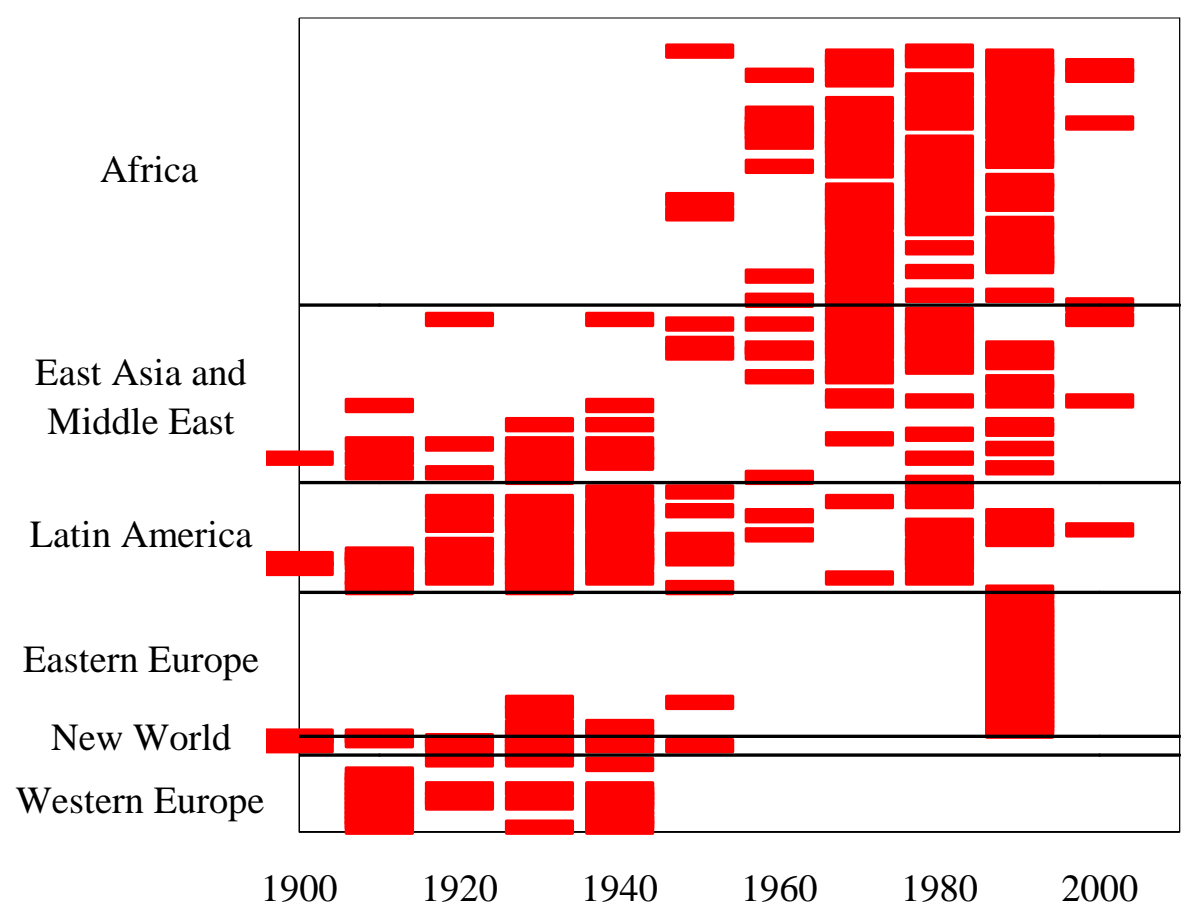

Source: Maddison (2001).

= Indicates occurrence of a severe output contraction (an annual fall in per capita real GDP of at least 8 percent) in the ten-year period starting in the indicated year. 
Figure 8. Growth and Volatility of Per Capita Real GDP 1900-2000 1/

Average Growth

(percent, by decade )

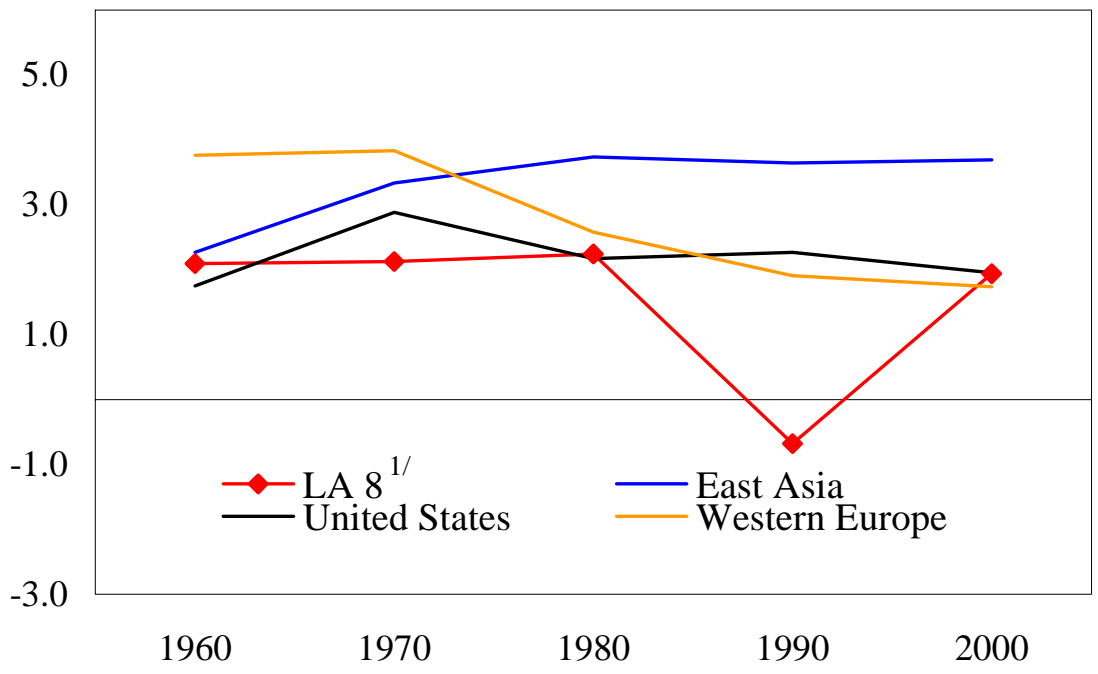

Average Standard Deviation

(percent, by decade)

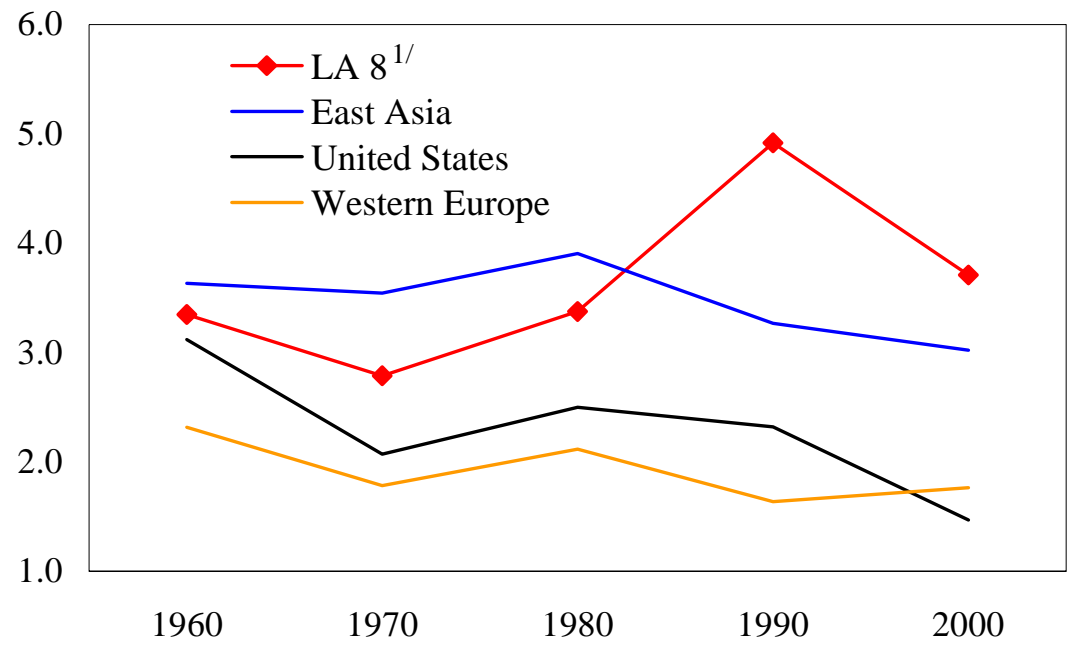

Source: Maddison (2001).

1/ LA8 includes Argentina, Brazil, Chile, Colombia, Mexico, Peru, Uruguay, and Venezuela. 
Figure 9. Per Capita Real GDP, 1900-2001 (thousand, 1990 U.S. dollars)

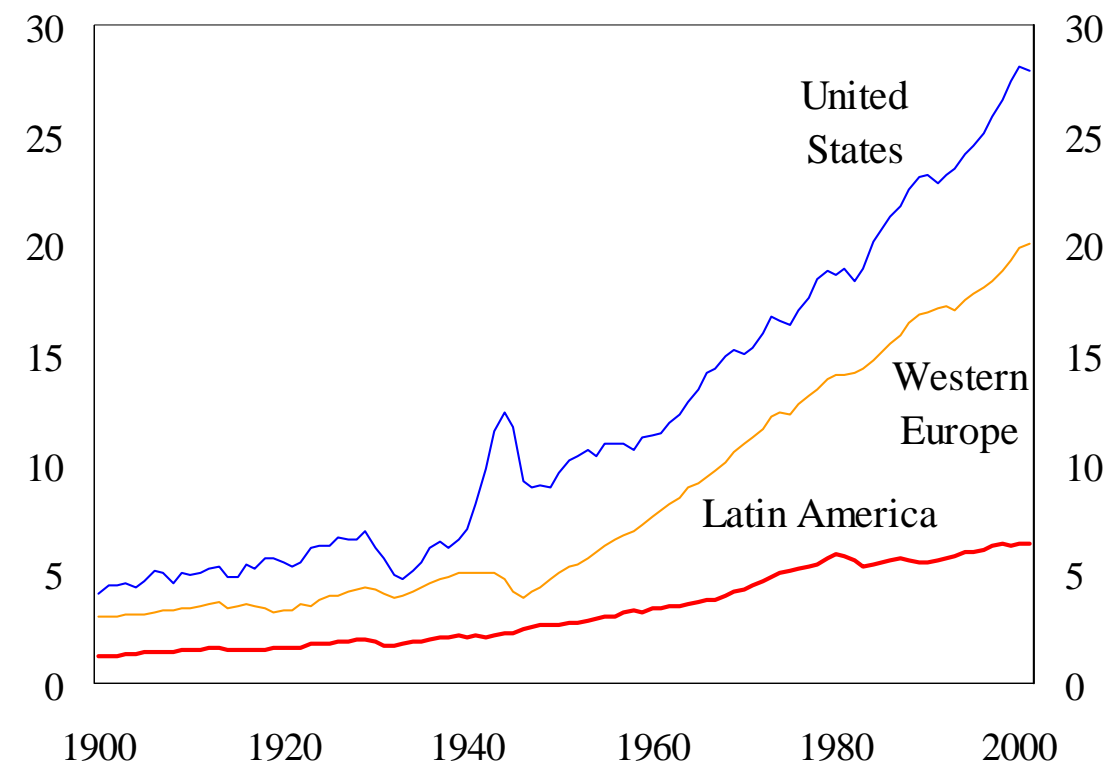

Source: Maddison (2001).

Figure10. Composition of Growth Cycles (in percent)

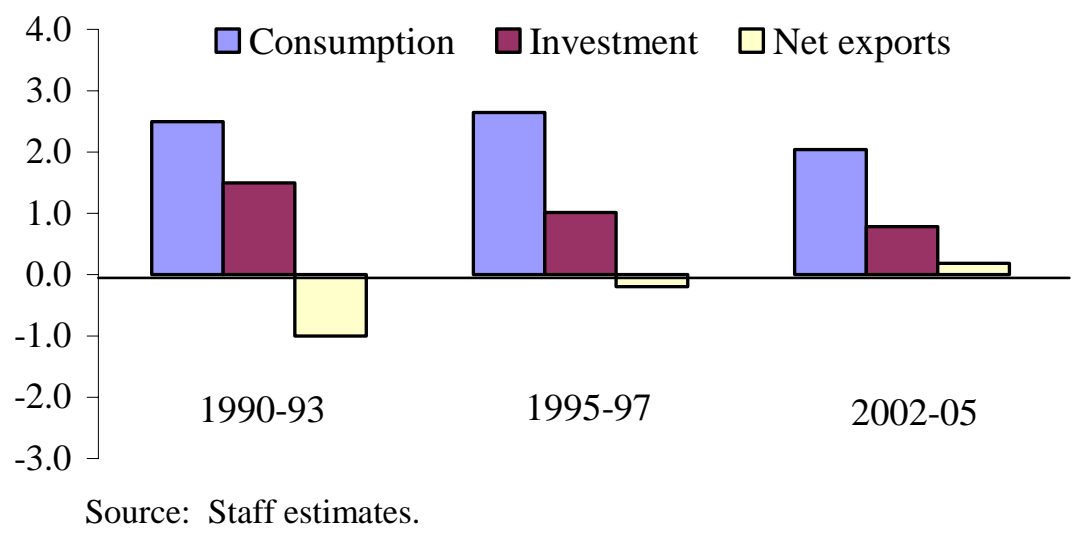


Figure 11. Annual Inflation Rate (in percent)

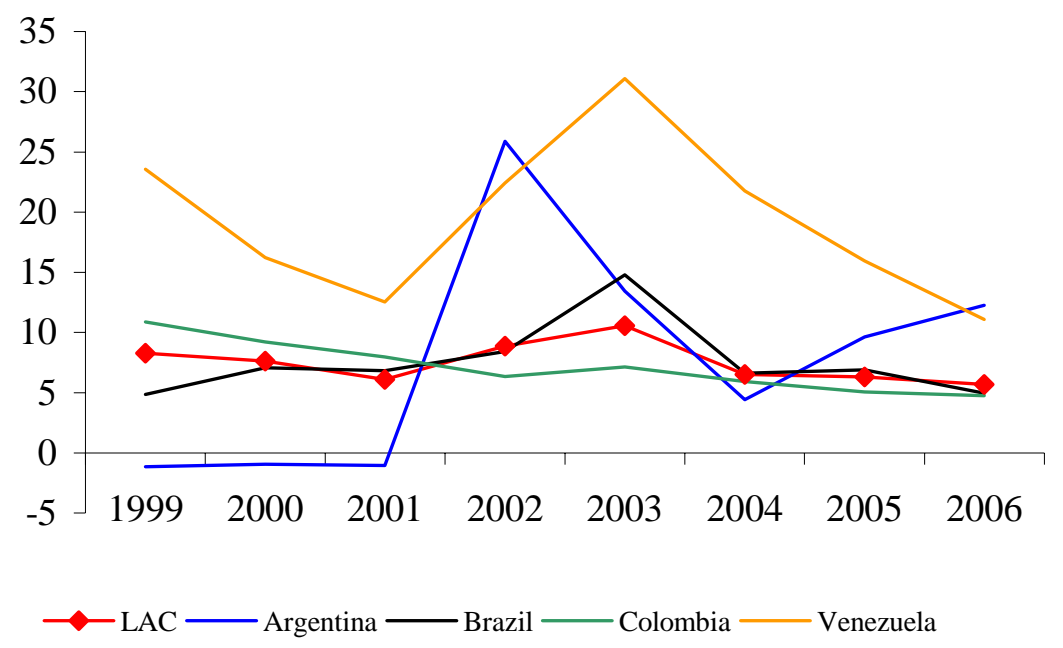

Source: Staff estimates.

Figure 12. Fiscal Policy During Cyclical Upswings (in percent of GDP)

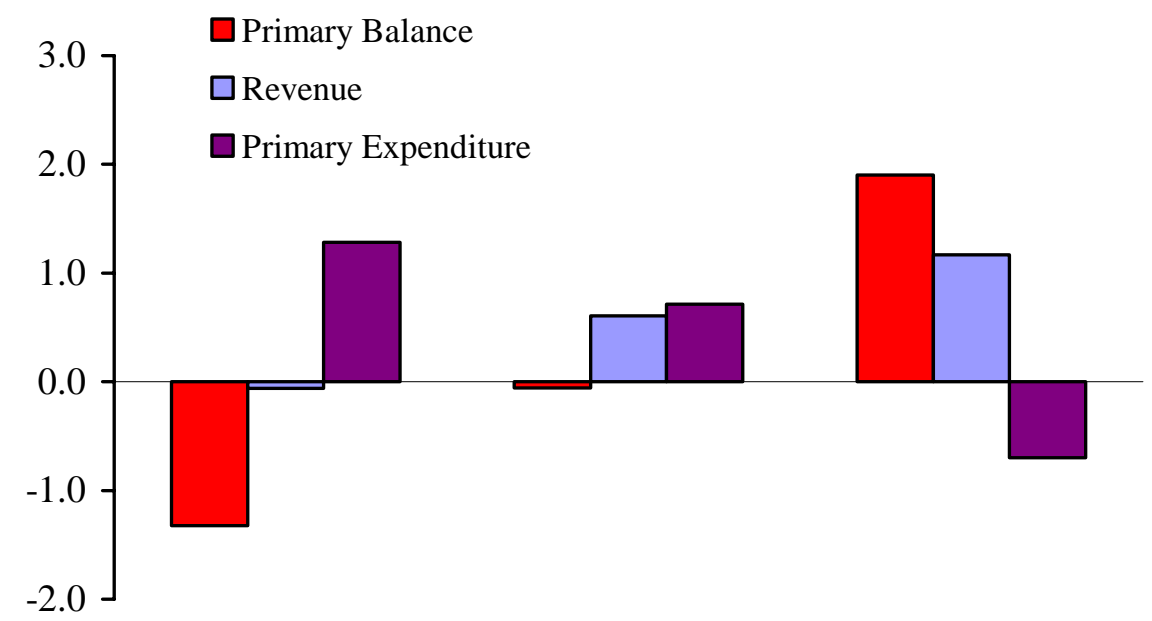

Source: Staff estimates. 
Figure 13. Contributions to Change in Public Debt 2002-2005 1/

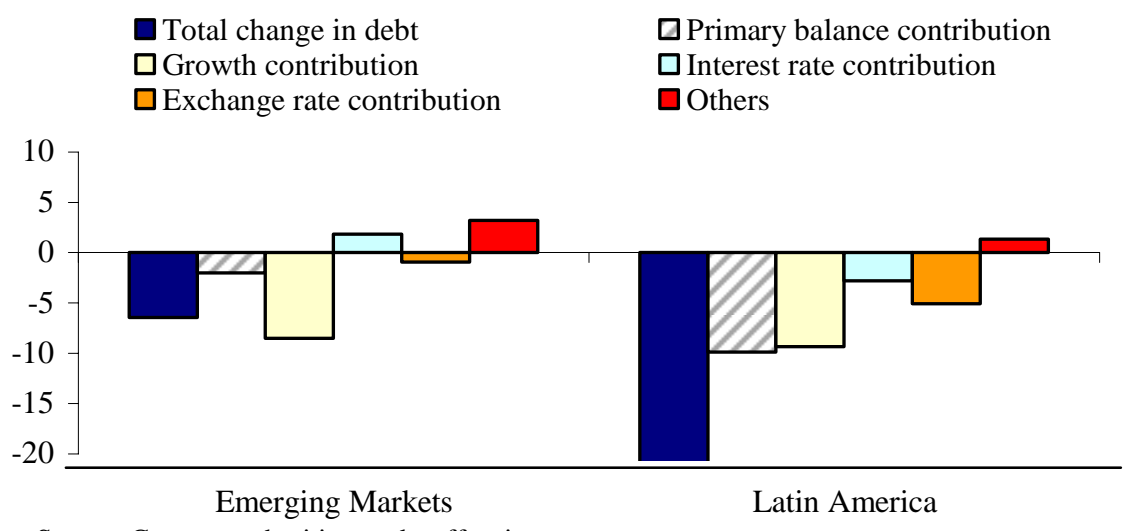

Source: Country authorities; and staff estimates.

1/ Weighted averages.

Figure 14. Share of Foreign Currency Bonds

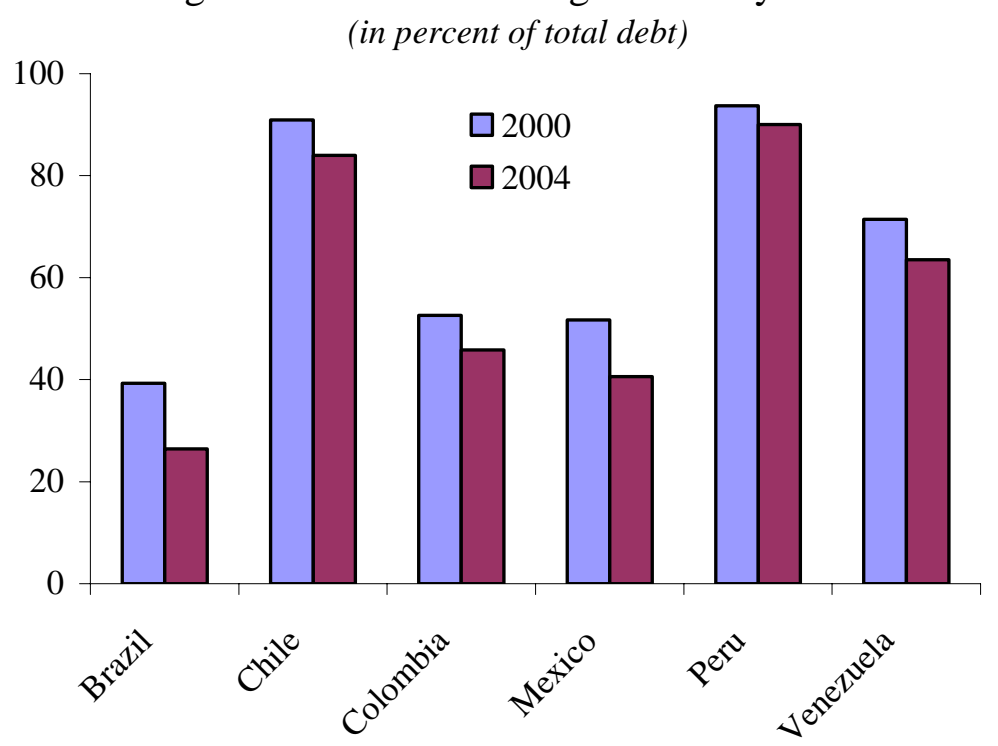

Source: Staff estimates. 
Figure 15. Public Debt in Latin America (in percent of GDP)

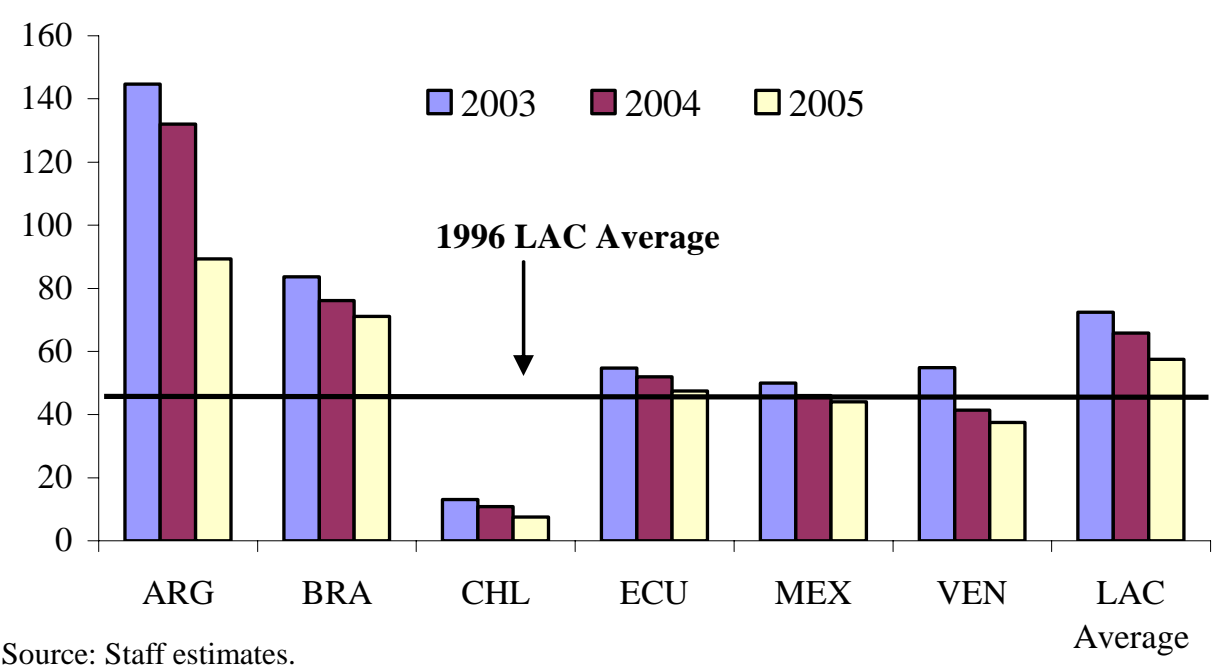

Figure 16. Net Interest Margins of the Banking Sector 1/ (in percent)

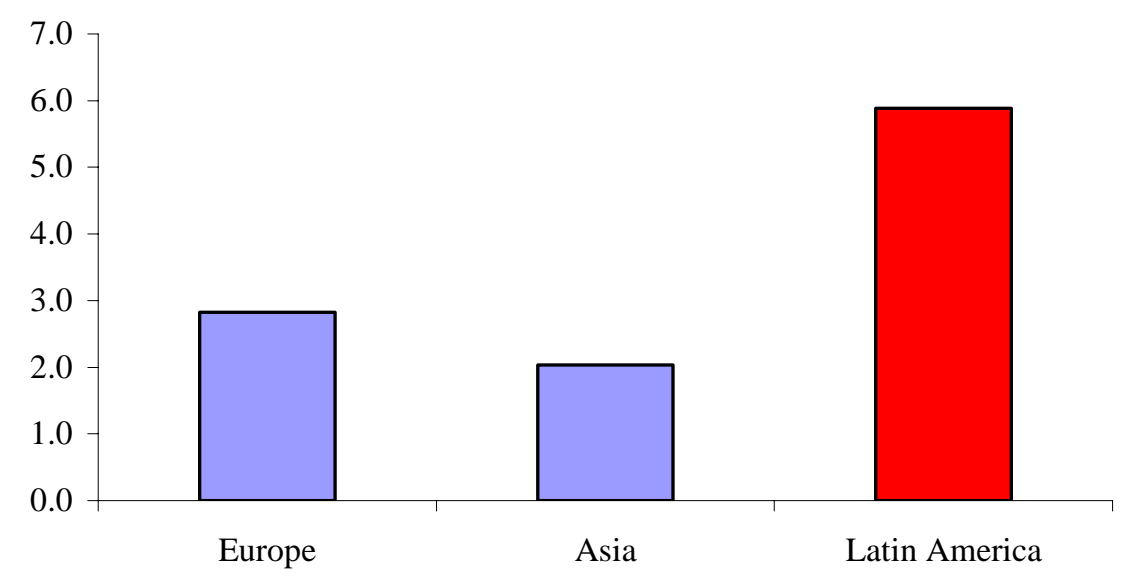

Source: Staff estimates.

1/ Averages for 1995-2004 for selected countries in each region. 
Figure 17. Number of Procedures in Starting a Business

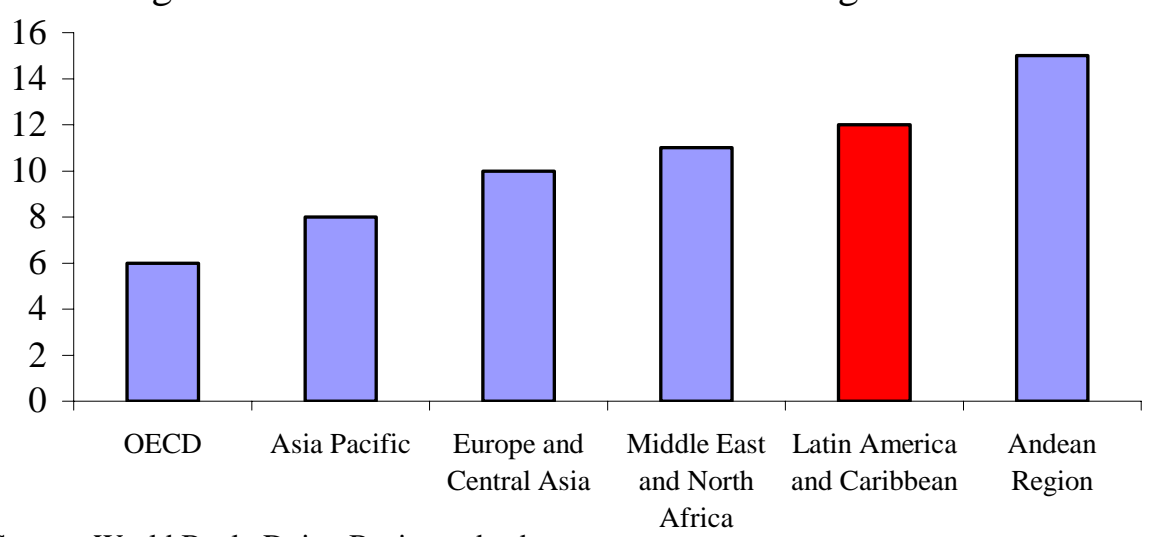

Source: World Bank, Doing Business database.

Note: OECD denotes the member countries of the Organization for Economic Cooperation and Development.

Figure 18. Contract Enforcement: Procedural Complexity Index (in percent)

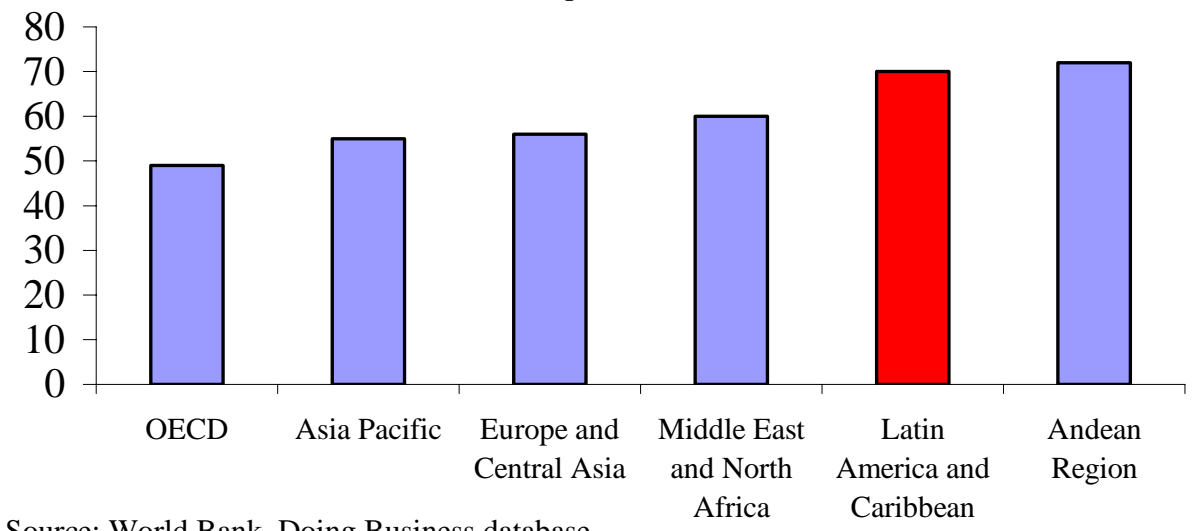

Note: OECD denotes the member countries of the Organization for Economic Cooperation and Development. 